\title{
Em busca do Deus perdido em Machado de Assis
}

\author{
Douglas Rodrigues da Conceição
}

\section{SciELO Books / SciELO Livros / SciELO Libros}

FERRAZ, S., et al.,orgs. Deuses em poéticas: estudos de literatura e teologia [online]. Belém: UEPA; Campina Grande: EDUEPB, 2008. 364 p. ISBN 978-85-7879-010-3. Available from SciELO Books $<\underline{\text { http://books.scielo.org }>\text {. }}$

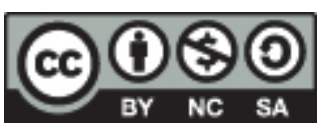

All the contents of this work, except where otherwise noted, is licensed under a Creative Commons Attribution-Non Commercial-ShareAlike 3.0 Unported.

Todo o conteúdo deste trabalho, exceto quando houver ressalva, é publicado sob a licença Creative Commons Atribuição Uso Não Comercial - Partilha nos Mesmos Termos 3.0 Não adaptada.

Todo el contenido de esta obra, excepto donde se indique lo contrario, está bajo licencia de la licencia Creative Commons Reconocimento-NoComercial-CompartirIgual 3.0 Unported. 


\section{Em busca do Deus perdido em Machado de Assis}

Douglas Rodrigues da Conceição 


\section{obibregr zuser ob spendering cierar sib obsribsive me}

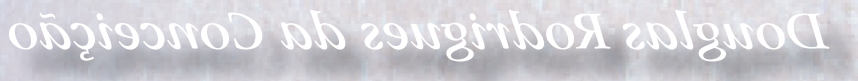


CONCEIÇÃO, Douglas Rodrigues da*

Para o centenário da morte de Machado de Assis...!

\title{
1. Bentinho: o filho da Promessa
}

\author{
"Minha mãe era temente a Deus; sabes disto, \\ das suas práticas religiosas, e da fé pura que as animava."
}

Bentinho

A trajetória dos estudos sobre a literatura de Machado de Assis demonstra claramente um afastamento das questões que serão desenvolvidas aqui. Esquivando-nos da distensão que comumente se faz das críticas sociológica e biográfica (estudos cristalizados por muito tempo como horizonte de interpretação da obra machadiana), decidimos focar nosso olhar em torno da imagem antropológica construída pela estética machadiana e permanecer no caminho que iniciamos em Fuga da promessa e nostalgia do divino (2004). O que queremos dizer é que mesmo possuindo a maior fortuna crítica entre a constelação das obras de literatura brasileira, o legado machadiano, como bem observou Alfredo Bosi em $O$ enigma do olhar, carecia de um trabalho que pudesse dar ênfase à questão religiosa e é exatamente sobre este aspecto que tentamos nos debruçar. Tomamos essa questão como nossa principal questão. Como então faríamos para que a questão religiosa, até então afastada da tradição interpretativa da literatura machadiana, fosse levada à superfície do texto? Pretendíamos nos apropriar do texto machadiano buscando o efeito que nossa interpretação poderia produzir quando confrontada com o que pertence ao próprio texto: o seu excesso de sentido e sua maneira particular de inscrição na realidade. Distanciando-nos, portanto, da fortuna crítica machadiana que fazia resplandecer sobre as obras do autor de Dom Casmurro uma espécie de sentido verdadeiro do texto ou o que seria próprio chamar de ontologia do texto machadiano, partimos da compreensão de que a denotação emergente dos textos literários advém de elementos do próprio texto, que por seu turno atuam como condicionantes do processo de

\footnotetext{
* Douglas Rodrigues da Conceição é doutor em Ciências da Religião pela Universidade Metodista de São Paulo (UMESP) e professor Adjunto do Departamento de Filosofia e Ciências Sociais da Universidade do Estado do Pará (UEPA). Email: abismos@gmail.com
} 
operação de novos sentidos.

Em Fuga da promessa e nostalgia do divino elegemos como foco de análises a antropologia machadiana, que foi ordenada pela relação ser humano $v s$ Deus. Deparamo-nos naquele momento com uma questão particular relacionada à personagem Bento Santiago, do romance Dom Casmurro, que era a questão da promessa.

A existência da dimensão paratextual ${ }^{173}$ do capítulo A promessa provocou um efeito potencializador da questão teológica no romance Dom Casmurro, que era por sua vez o foco inicial da nossa pesquisa naquela ocasião. Revelava-se, circunscritamente à promessa, uma imagem de Deus, uma imagem do ser humano capaz de abrir-se ao transcendente e uma crise existencial deste mesmo ser humano em razão da forma com que foi posto em relação com esse Deus. Observemos em que termos a promessa foi realizada:

\section{Capítulo XI / A PROMESSA}

Tão depressa vi desaparecer o agregado no corredor, deixei o esconderijo, e corri à varanda do fundo. Não quis saber de lágrimas nem da causa que as fazia verter a minha mãe. A causa eram provavelmente os seus projetos eclesiásticos, e a ocasião destes é a que vou dizer, por ser já então história velha; datava de dezesseis anos.

Os projetos vinham do tempo em que fui concebido. Tendo-lhe nascido morto o primeiro filho, minha mãe pegou-se com Deus para que o segundo vingasse, prometendo, se fosse varão, metê-lo na Igreja. Talvez esperasse uma menina. Não disse nada a meu pai, nem antes, nem depois de me dar à luz, contava fazê-lo quando eu entrasse para a escola, mas enviuvou antes disso. Viúva, sentiu o terror de separar-se de mim; mas era tão devota, tão temente a Deus, que buscou testemunbas da obrigação, confiando a promessa a parentes e familiares. Unicamente, para que nos separássemos o mais tarde possível, fez-me aprender em casa primeiras letras, latim e doutrina, por aquele Padre Cabral, velho amigo do tio Cosme, que ia lá jogar às noites.

Prazos largos são fáceis de subscrever; a imaginação os faz infinitos. Minha mãe esperou que os

173 Cf. Gérard GENETTE. Palimpsestes. Paris: Éditions du Seiul, 1982. 
anos viessem vindo. Entretanto ia-me afeiçoando à idéia da Igreja; brincos de criança, livros devotos, imagens de santos, conversações de casa, tudo convergia para o altar quando íamos à missa, dizia-me sempre que era para aprender a ser padre, e que reparasse no padre, não tirasse os olhos do padre. Em casa, brincava de missa, - um tanto às escondidas, porque minha mãe dizia que missa não era cousa de brincadeira. Arranjávamos um altar, Capitu e eu. Ela servia de sacristão, e alterávamos o ritual, no sentido de dividirmos a hóstia entre nós, a hóstia era sempre um doce. No tempo em que brincávamos assim, era muito comum ouvir à minha vizinha: "Hoje há missa?" Eu já sabia o que isto queria dizer, respondia afirmativamente, e ia pedir hóstia por outro nome Voltava com ela, arranjávamos o altar, engrolávamos o latim e precipitávamos as cerimônias. Dominus, non sum dignus... Isto, que eu devia dizer três vezes, penso que só dizia uma, tal era a gulodice do padre e do sacristão. Não bebíamos vinho nem água; não tínhamos o primeiro, e a segunda viria tirar-nos o gosto do sacrifício.

Ultimamente não me falavam já do seminário, a tal ponto que eu supunha ser negócio findo. Quinze anos, não havendo vocação, podiam antes o seminário do mundo que o de S. José. Minha mãe ficava muita vez a olhar para mim, como alma perdida, ou pegava-me na mão, a pretexto de nada, para apertá-la muito. ( MACHADO DE ASSIS, 1985, pp. 819-820, itálico nosso) ${ }^{174}$

Procuramos entender a promessa como questão central do romance. Da promessa até a malograda vida de Bentinho ao lado de Capitu, o romance passou a ter como fator de significação, segundo nosso olhar, a forma como o Deus da promessa se revelava para dona Glória, mãe de Bentinho e autora da promessa, e a maneira com que Bentinho, o prometido, se relacionava com Deus e Este com ele. Como ele mesmo denuncia: "Minha mãe era temente a Deus; sabes disto, das suas práticas religiosas, e da fé pura que as animava." $\mathrm{E}$ ainda: "A promessa, feita com fervor, aceita com misericórdia, foi guardada por ela, com alegria, no mais íntimo do coração. Penso que lhe senti o sabor da felicidade no leite que me deu a mamar.”(Op. cit., p. 889). Do ponto 174 Todos os itálicos no texto de Machado de Assis são de nossa autoria. 
de vista teológico, não pretendíamos perceber a revelação de Deus às personagens religiosas como um processo condicionado pela própria antropologia emergente do romance, o que significa dizer que não desejávamos ver a forma com que o Deus da promessa se manifestava em razão da vontade do ser humano. Mesmo que em alguns momentos o Deus da promessa figurasse no romance com funções específicas na vida de Bentinho e de dona Glória, ao atender aos pedidos encaminhados aos céus, diríamos que Ele, antes de ser morto com o fim da promessa, transparecia no texto machadiano como mantenedor e organizador da vida das personagens e também como centro de referência e de sentido nos momento de crise existencial. Havia nas personagens machadianas certa esperança na efetivação da presença de Deus diante das questões trágicas de suas vidas. Observemos a atitude de dona Glória ao ver nascer morto o seu primeiro filho: "Tendo-lhe nascido morto o primeiro filho, minha mãe pegou-se com Deus para que o segundo vingasse, prometendo, se fosse varão, metê-lo na Igreja." Percebamos a significação do ato de apegar-se a Deus. A experiência negativa de dona Glória reverte-se, sob a égide do mistério de Deus, numa forma manifesta de esperança e de consolação. As vidas das personagens machadianas envolvidas na promessa, inegavelmente, estão ligadas ao Deus cristão.

A consciência de ter sido prometido faz de Bentinho, o menino, um ser que reconhece em Deus o ponto de chegada de suas experiências religiosas. Buscava os céus com muita intensidade quando menino. Os aspectos relacionais homem $v$ s Deus e Deus $v s$ homem, em determinadas partes do romance Dom Casmurro representam, do ponto de vista teológico, a capacidade de Deus em revelar-se ao ser humano. Do ponto de vista antropológico, a relação homem $v s$ Deus denuncia a dimensão do ser humano aberta às experiências com o que o ultrapassa. Trata-se, pois, do reconhecimento do aspecto finito do ser humano. Bentinho é uma personagem machadiana que notadamente carrega consigo a certeza de sua impotência diante das contradições de sua vida e por isso, em muitos momentos, pôde reconhecer os céus como elemento representativo de suas experiências religiosas. O capítulo XX de Dom Casmurro espelha emblematicamente a dimensão experiencial da vida de Bentinho:

Capítulo XX / MIL PADRE-NOSSOS

$\mathrm{E}$

MIL AVE-MARIAS

Levantei os olhos ao céu, que começava a embrus- 
car-se, mas não foi para vê-lo coberto ou descoberto. Era ao outro céu que eu erguia a minha alma; era ao meu refúgio, ao meu amigo. E então disse de mim para mim: "Prometo rezar mil padre-nossos e mil ave-marias, se José Dias arranjar que eu não vá para o seminário".

A soma era enorme. A razão é que eu andava carregado de promessas não cumpridas. A última foi de duzentos padre-nossos e duzentas ave-marias, se não chovesse em certa tarde de passeio a Santa Teresa. Não choveu, mas eu não rezei as orações. Desde pequenino acostumara-me a pedir ao céu os seus favores, mediante orações que diria, se eles viessem. Disse as primeiras, as outras foram adiadas, e à medida que se amontoavam iam sendo esquecidas. Assim cheguei aos números vinte, trinta, cinqüenta. Entrei nas centenas e agora no milhar. Era um modo de peitar a vontade divina pela quantia das oraçóes; além disso, cada promessa nova era feita e jurada no sentido de pagar a dívida antiga. Mas vão lá matar a preguiça de uma alma que a trazia do berço e não a sentia atenuada pela vida! O céu fazia-me o favor, eu adiava a paga. Afinal perdi-me nas contas.

"Mil, mil", repeti comigo.

Realmente, a matéria do benefício era agora imensa, não menos que a salvação ou o naufrágio da minha existência inteira. Mil, mil, mil. Era preciso uma soma que pagasse os atrasados todos. Deus podia muito bem, irritado com os esquecimentos, negar-se a ouvir-me sem muito dinheiro... Homem grave, é possível que estas agitações de menino te enfadem, se é que não as achas ridículas. Sublimes não eram. Cogitei muito no modo de resgatar a dívida espiritual. Não achava outra espécie em que, mediante a intenção, tudo se cumprisse, fechando a escrituração da minha consciência moral sem deficit. Mandar dizer cem missas, ou subir de joelhos a ladeira da Glória para ouvir uma, ir à Terra Santa, tudo o que as velhas escravas me contavam de promessas célebres, tudo me acudia sem se fixar de vez no espírito. Era muito duro subir uma ladeira de joelhos; devia feri-los por força. A Terra Santa ficava muito longe. As missas eram numerosas, po- 
diam empenhar-me outra vez a alma... (1985, pp. 830-831)

Um fato marcante neste trecho de Dom Casmurro é a imagem de um céu possivelmente mudo em razão de uma inicial ausência do sentido de Deus na vida de Bentinho: "Era ao outro céu que eu erguia a minha alma; era ao meu refúgio, ao meu amigo." Raimundo Faoro, diante do mesmo trecho, sugere que a imagem do céu contida neste fragmento representa a dissolução do amparo dos símplices, servindo para mascarar a consciência, desviar os remorsos e barganhar, de má fé, favores e esperanças. ${ }^{175}$ Afirmamos em Fuga da promessa e nostalgia do divino que as situações de natureza existencial da vida de Bentinho, até mesmo as minoritárias, eram resolvidas por meio dos pedidos aos céus e sempre tributárias da promessa feita por sua mãe. ${ }^{176}$ Queríamos com isto apontar que se pôde perceber, descritivamente, em Dom Casmurro, uma imagem de Deus semelhante a de um Deus controlador e mantenedor da vida. O mundo que chamamos a pouco de mundo sem Deus é exatamente o mundo que se abre diante da vida de Bentinho quando este o imaginou livre da promessa realizada por sua mãe. A imagem do Deus da promessa passou a sofrer um processo de fenecimento. Ela foi se apagando no momento em que Bentinho percebeu que os novos imperativos de sua vida eram a liberdade, a autonomia e o amor por Capitu; tais imperativos substituíam o lugar do Seminário São José, ou seja, substituíam a promessa.

Seguindo por este caminho, pudemos perceber que a precariedade que se abria diante da vida de Bentinho revelava também a presença de um ser humano individualizado dentro do romance Dom Casmurro. Para Faoro, esta constatação deve ser interpretada como a dissolução da imagem do homem religioso e do cristão católico por terem perdido de alguma forma as raízes que os alimentavam e, que em algum momento, lhes insuflaram o sentimento da divindade. A imagem desta antropologia machadiana pode ser vista como a do ser humano que desejou ver sua vida fora dos domínios da Igreja, autônoma e que se bastava em si mesma. ${ }^{177}$ Poderíamos pensar numa perda do sentido de Deus. Em diversos momentos essa imagem da antropologia machadiana emerge de sua estética como no seguinte trecho do romance Helena (1876). O fragmento é relacionado à personagem Dr. Camargo:

175 Cf. Raimundo FAORO, A pirâmide e o trapézio, p. 400.

176 Cf. Douglas CONCEIÇÃO, Fuga da promessa..., p. 93.

177 Cf. Raimundo FAORO, A pirâmide e o trapézio, p. 392. 
"Quanto aos sentimentos religiosos, a aferi-los pelas ações, ninguém os possuía mais puros. Era pontual no cumprimento dos deveres de bom católico. Mas só pontual; interiormente, era incrédulo.” (1985, p. 275)

O ocaso do sentido de Deus para as personagens da estética machadiana parece-nos ser um dos elementos que compõem circularmente a sua poética. A insistência de determinados temas em figurar no legado machadiano pode ser entendida, sem maior esforço, como o que nomearemos de circularidade temática da escrita. Como sugere Faoro, o fenecimento de Deus pode ser visto através da muda constelação de estrelas em que se tornou o céu que era antes povoado pelo Deus de Abraão. ${ }^{178}$ Contudo, devemos ressalvar mais uma vez que, antes da crise do sentido de Deus figurar na estética machadiana, é possível observar a significação que Ele constituía para a vida das personagens. Em Helena, romance de 1876 , percebe-se a notável presença do padre Melchior. À guisa de digressão, vale ressaltar que as obras machadianas estão povoadas por padres, protonotários, cônegos, etc. O padre Melchior, um dos testamenteiros do Conselheiro Vale, com um discurso moralizador, o que nos remete às amarras instrumentalizadoras da vida que a fé institucionalizada sempre trouxe consigo, profere um interessante e duro discurso a Estácio:

\section{Capítulo XXIII}

— És forte? perguntou o padre.

- Sou.

- Crês em Deus?

Estácio estremeceu e olhou para o ancião, sem responder. Melchior insistiu:

- Crês?

- Essa pergunta...

-É menos ociosa do que parece. Não basta supor que se crê; nem basta crer à ligeira, como na existência de uma região obscura da Ásia, onde nunca se pretende pôr os pés. O Deus de que falo, não é só essa sublime necessidade do espírito, que apenas contenta alguns filósofos; falo-te do Deus criador e remunerador, do Deus que lê no fundo de nossas consciências, que nos deu a vida, que nos há de dar a morte e, além da morte, o prêmio ou o castigo. Crês?

- Creio.

- Pois bem, tu transgrediste a lei divina, como a

178 Cf. Raimundo FAORO, A pirâmide e o trapézio, p. 398. 
lei humana, sem o saber. Teu coração é um grande inconsciente; agita-se, murmura, rebela-se, vaga à feição de um instinto mal-expresso e mal compreendido. O mal persegue-te, tenta-te, envolve-te em seus liames dourados e ocultos; tu não o sentes, não o vês; terás horror de ti mesmo, quando deres com ele de rosto. Deus que te lê, sabe perfeitamente que entre o teu coração e tua consciência há um véu espesso que os separa, que impede esse acordo gerador do delito.

- Mas que é, padre-mestre?

Melchior inclinou-se e encarou o moço. Os olhos, fitos nele, eram como um espelho polido e frio, destinado a reproduzir a imagem do que lhe ia dizer.

- Estácio, disse Melchior pausadamente, tu amas tua irmã. (1985, p.p 363-364)

A nítida imagem que o padre Melchior apresenta de Deus é a imagem do Deus mantenedor, organizador da vida e que pune; trata-se do Deus que dá, mas que também cobra: "O Deus de que falo, não é só essa sublime necessidade do espírito, que apenas contenta alguns filósofos; falo-te do Deus criador e remunerador, do Deus que lê no fundo de nossas consciências, que nos deu a vida, que nos há de dar a morte e, além da morte, o prêmio ou o castigo" (Id. ib, p. 363-364). Raimundo Faoro entendeu, a partir desse mesmo fragmento, que o crer e o viver devem ser mantidos como um importante consórcio ou como duas dimensões inseparáveis. ${ }^{179} \mathrm{O}$ ser humano que as separar certamente estará diante da agudeza de uma vida que se move por intermédio das experiências que beiram os limites de um mundo autônomo. O Deus para o qual se dirige a conjunção entre o crer e o viver é um Deus pessoal, imprescindível à condição humana e que oferta a garantia de um prêmio ou de um castigo, como afirma o padre Melchior. Entendemos também que não se deve somente olhar para as possíveis ações objetivas de Deus em relação à vida do ser humano machadiano, mas também para o sentido que ele assume. Este sentido é facilmente identificável pela sua incondicionalidade. Deus se apresenta como símbolo mesmo de resposta ao ser humano quando a própria condição humana encontra-se em seu trágico limite. Do ponto de vista da experiência religiosa poderíamos dizer que, em alguns momentos, o Deus que se revela na estética machadiana assume o sentido de realidade última.

179 Cf. Raimundo FAORO, A pirâmide e o trapézio, p. 399. 
Mesmo com este quadro criado em torno das imagens de Deus e de sua relação com o ser humano que emerge da literatura machadiana, o nosso foco foi presidido pelo surgimento de uma imagem gris de Deus, que no caso de Dom Casmurro foi também acompanhada de um processo de desordenamento do mundo da personagem Bentinho. A perda do sentido de Deus pode ser constatada ainda nos chamados romances da primeira fase quando as questões relativas à existência do ser humano e Deus aparecem. Um importante exemplo pode ser visto no romance Iaiá Garcia (1878). Raimundo Faoro vê semelhanças entre a angústia de Estácio do romance Helena e a que é encontrada na jovem Iaiá, pois diante de seu abismo existencial não consegue encontrar amparo nem mesmo nos céus. Mergulhada, possivelmente, na inquietude que o amor provoca, Iaiá percebe-se desamparada por ter sobre si uma questão existencial em aberto:

Capítulo XIII

A tranqüilidade era aparente. Nessa noite, recolhida aos aposentos, a moça deu largas a dous sentimentos opostos. Entrou ali prostrada. - Que estou fazendo? Disse ela apertando a cabeça entre os punhos. Abriu a veneziana da janela e interrogou o céu. O céu não lhe respondeu nada; esse imenso taciturno tem olbos para ver, mas não tem ouvidos para ouvir. A noite era clara e serena; os milhões de estrelas que cintilavam pareciam rir dos milhões de angústias da Terra. Duas delas despegaram-se e mergulharam na escuridão, como os figos verdes do Apocalipse. Iaiá teve a superstição de crer que também ela mergulharia ali dentro e cedo. Então, fechou os olhos ao grande mudo, e alçou o pensamento ao grande misericordioso, ao Céu que se não vê, mas de que há uma parcela ou um raio no coração dos símplices. Esse ouviua e confortou-a; ali achou ela apoio e fortaleza. Uma voz parecia dizer-lhe: - Prossegue a tua obra; sacrifica-te; salva a paz doméstica. Restaurada a alma, ergueu-se do primeiro abatimento. Quando abriu de novo os olhos, não foi para interrogar, mas para afirmar, - para dizer à noite que naquele corpo franzino e tenro havia uma alma capaz de encravar a roda do destino.

Tarde conciliou o sono. Já dia claro, sonhou que ia calcando a beira de um abismo, e que uma figura 
de mulher lhe lançava as mãos à cinta e a levantava ao ar como uma pluma. Pálida, com o olhar desvairado, a boca irônica, essa mulher sorria, de um sorriso triunfante e mau; murmurava algumas frases truncadas que ela não entendia. Iaiá bradoulhe em alta voz: - Dize-me que não me amas e eu te amarei como te amava! Mas a mulher sacudindo a cabeça com um gesto trágico, e colando-lhe os lábios nos lábios, soprou ali um beijo convulso e frio como a morte. Iaiá sentiu-se desfalecer e rolou ao abismo [...] (1985, p. 473)

Poderíamos nos perguntar o que verdadeiramente pode ser encontrado no coração dos símplices mesmo que em pequena parcela ou apenas como um pequeno raio. O que é ou quem é esse que a ouviu, a confortou e a apoiou, mesmo sabendo Iaiá que o céu teria olhos para vê-la, mas nada poderia lhe responder, pois "não tem ouvidos para ouvir." O esquecimento da imagem de Deus, bem como o sentido religioso que deveria rodear as metáforas que servem de sinalização de sua Presença, ficam cada vez mais acentuadamente vazios e desprovidos de significação para o ser humano da estética machadiana.

A morte de Deus em Dom Casmurro fez o ser humano machadiano assumir-se diante da vida de forma intransitiva. Sem o além e sem as garantias do céu, o que tem de ser afirmado é a possibilidade de uma vida imanente. Paralelamente ao mundo regido por Deus no romance Dom Casmurro existe um outro movido pela pulsão erótica do ser humano da estética machadiana. Não queremos dizer que um mundo regido por Deus ou pelo Deus da causalidade como Aquele que é revelado em Dom Casmurro exclui a dimensão erótica da vida humana, contudo o que se quer afirmar é que a quebra da promessa potencializou nosso olhar em torno de tal questão. "As cinzas de um incêndio extinto estão em toda parte, em todas as consciências [...]"180 e, por isso, não há mais Deus no espaço literário machadiano. Portanto, emerge da estética machadiana um novo eixo em torno do qual passa a girar o ser humano. É a sinfonia ditirâmbica da vida que passa a ordenar as ações do ser humano do mundo machadiano. É por causa da promessa de amor à Capitu que Bentinho decidiu abandonar a promessa de sua mãe.

Mesmo mergulhado em suas consternações, Bento Santiago foi capaz de reconhecer que o amor que sentia por Capitu era de fato 
uma ferida aberta e que ainda latejava dentro dele o acorde de Eros. Diante do que expomos anteriormente, Capitu poderia ser considerada de fato aquilo que tomava incondicionalmente Bento Santiago: "Capitu era tudo e mais que tudo; não vivia nem trabalhava que não fosse pensando nela [...]" (1985, p. 919). A experiência mais radical da transcendência, como bem assinala Leonardo Boff, é a experiência do enamoramento ou do amor, por tocar incondicionalmente a profundidade de nós mesmos. Para Leonardo Boff a experiência do enamoramento é uma experiência de êxtase, extática, fora da realidade, portanto, religiosa. ${ }^{181}$

\section{Capítulo XII / NA VARANDA}

Naquele instante, a eterna Verdade não valeria mais que ele, nem a eterna Bondade, nem as demais Virtudes eternas. Eu amava Capitu! Capitu amava-me! E as minhas pernas andavam, desandavam, estacavam, trêmulas e crentes de abarcar o mundo. Esse primeiro palpitar da seiva, essa revelação da consciência a si própria, nunca mais me esqueceu, nem achei que lhe fosse comparável qualquer outra sensação da mesma espécie. (1985, p. 821)

\section{Memórias Póstumas: A curta ponte entre a vida e a morte.}

"Viver somente, não te peço mais nada. Quem me pôs no coração este amor da vida [...]"

Brás Cubas

A dimensão religiosa que procuramos a partir de $M p B C$ poderá ser encontrada sob o prisma das relações estabelecidas no horizonte da vida e através da capacidade de ação e reação que a nova imagem antropológica da estética machadiana possui quando é defrontada profundamente com senso de finitude. Daí a importância de se descobrir um significado maior para existência que pudesse imprimir sobre ela o tom intransitivo peculiar aos processos de intensificação vida e ao mesmo tempo resguardá-la do pólo metafísico e negativo da eternidade. Pode-

181 Cf. Leonardo BOFF, Tempo de transcendência, p. 42. Vale ressaltar que o exemplo usado por Leonardo Boff é a experiência do amor de Bentinho por Capitu. 
mos concluir até aqui que a intensificação da vida não deve ser equivalente, no espaço literário machadiano, ao desejo de eternidade. Se o ser humano for de fato o espelho no qual se torna nítida a teia de relação construída entre o finito e o infinito ${ }^{182}$, certamente, a polaridade do infinito, do ponto de vista da nova imagem do humano machadiano, será representada pela intransitividade da vida. O ser humano machadiano aceita o risco de transcender à tragédia que se põe diante da vida humana e ao sentimento de vacuidade e, por isso, se lança para além deles nos limites da própria vida. O protagonista das memórias póstumas se põe a perguntar o "Que há entre a vida e a morte?" "Uma curta ponte" é a resposta que encontra $(1985$, p. 620). É preciso, portanto, lançar-se à travessia dessa ponte. Sem correr os riscos dessa travessia não há como estabelecer nenhuma forma de experiência. ${ }^{183}$ Paradoxalmente, dentro das memórias póstumas, o centro hermenêutico se constitui a partir da afirmação da incondicionalidade da vida: "Ânimo, Brás Cubas, não me sejas palerma [...] trata de saborear a vida; e fica sabendo que a pior filosofia é a do choramingas que se deita à margem do rio para o fim de lastimar o curso incessante das águas" (1985, p. 626). Só há um mal para quem se compraz com a festa da vida; "Porquanto, verdadeiramente há só uma desgraça: é não nascer" (1985, p. 614-615). A descoberta da intransitividade da vida significa também, para o ser humano machadiano, em nossa compreensão, a descoberta da dimensão religiosa nas experiências de vida. Ao tomar a vida como forma última de realização de sua expressão vital, o ser humano machadiano inaugura uma dimensão incondicional, porque é a partir desses impulsos que se consegue superar a finitude e alocar o senso de infinitude nos limites da própria vida. A intransitividade da vida torna-se, em certa medida, o horizonte para o qual se dirige o ser humano da estética machadiana. A justificativa para a morte de Brás Cubas nasceu exatamente de um impulso que pretendia aliviar o absurdo da vida.

O reconhecimento da ameaça do não-ser é uma prova de que o ser humano machadiano se lança à auto-afirmação da vida que acontece na imanência. ${ }^{184}$ Para Brás Cubas, a vida não deve se estender à eternidade. A questão da morte dentro das memórias póstumas deve ser tomada como uma dimensão que impede a continuidade de tudo que venha a ser uma forma de intensificação da vida e não como uma

182 Cf. Paul TILLICH, Teologia sistemática, p. 451.

183 Cf. Jürgen MOLTMANN, O espírito da vida, p. 34.

184 Tillich argumenta que a coragem de ser é a coragem de afirmar a nossa própria natureza por e sobre o que é acidental em nós. Cf. Paul TILLICH, A coragem de ser, p. 10. 
via para o salto à eternidade. A idéia das memórias pode ser vista como um recurso criado pelo narrador defunto para driblar o tempo, que segundo Brás Cubas é o ministro da morte. A recordação é uma maneira própria de retornar ao mesmo ou à experiência vivida e por isso a vida deve ser compreendida a partir de todo esforço que ofereça a ela a maior intensidade possível, pois a advertência de Cubas é categórica: "ninguém se fie - apenas - da felicidade presente."(1985, p. 518) "Reagi a mocidade, era preciso viver. Meti no Baú o problema da vida e da morte [...]" (1985, p. 547). O tom da intensidade das experiências de Brás Cubas é construído através uma paixão pela vida a partir da qual ela se torna intransitiva. A vida nas memórias póstumas ganha um significado maior do que a promessa da eternidade. A eternidade é para Cubas a representação do nada e o lugar para onde o punhado de pó, que é o destino do ser humano, será espalhado pela morte. (Id. Ib. p. 518). De acordo com Moltmann, é através dessa incondicional manifestação de auto-afirmação que o ser humano pode dissipar toda e qualquer instrumentalização moral da vida e dele mesmo em favor de uma livre intensificação vida. ${ }^{185}$ Portanto, entendemos que a vitalidade é o principal instrumento da sinfonia ditirâmbica que Brás Cubas compôs.

No capítulo $O$ Delírio, Brás Cubas, antes mesmo de sentir o hálito da morte, narra a viagem que fez através dos tempos. Sentiu-se transformado na Suma Teológica de S. Tomás, impressa num só volume. A teologia tomista tornou-se um alvo do humor machadiano. Brás Cubas dizia que a transformação em Suma Teológica deu ao seu "corpo a mais completa imobilidade" (1985, p. 520). Levado ao Éden por um hipopótamo, Brás Cubas viu surgir diante de si o vulto de uma mulher que se apresentou da seguinte forma:

- Chamam-me Natureza ou Pandora; sou tua mãe e tua inimiga.

$[\ldots]$

- Não te assustes, disse ela, minha inimizade não mata; é sobretudo pela vida que se afirma. (1985, p. 521)

185 Cf. Jürgen MOLTMANN, O espírito da vida, p. 89. A compreensão que temos de vitalidade deve, como aponta Moltmann, se distanciar do espírito hedonista que se instalou nas sociedades modernas. Ela aqui também não deve ser confundida com o impulso que levou a sociedade burguesa tardia ao endeusamento (culto) da saúde, ao culto do corpo e à exaltação da força vital como eficiência. Portanto, a vitalidade que surge do amor à vida deve se opor aos processos que nos entorpecem em nossas rotinas dentro de uma sociedade tecnocrata. Cf. Jürgen MOLTMANN, O espírito da vida, p. 90. 
No diálogo que segue, Brás Cubas demonstra certa preocupação com a sua existência ao perguntar à Pandora se ainda vive:"- Vivo? perguntei eu $[\ldots]$ como para certificar-me da existência" [...] "-Sim, verme, tu vives", respondeu Pandora. A estupefação de Brás Cubas diante da possibilidade do não-ser assume maiores proporções quando Pandora anuncia que a vida que lhe é cobrada naquele momento não passa da devolução de algo que a ele foi emprestado: "tu estás prestes de devolver-me o que te emprestei." (Op. cit., p. 521-522).

Pandora ou Natureza parece de fato conhecer toda a existência de Brás Cubas ao chamá-lo de grande lascivo. Certamente, ela relaciona a lascívia de Brás Cubas à sua paixão pela vida, ao intenso amor dispensado à Marcela e depois à Virgília: "Grande lascivo, espera-te a voluptuosidade do nada”. (Op. cit., p. 522)

A absurdidade que a possibilidade do não-ser apresenta aciona o nosso senso de auto-afirmação da vida. A vitalidade emerge diante da iminência da morte como incondicional manifestação de amor, plenificação e conservação da vida. Podemos nitidamente perceber que a súbita reação de Brás Cubas, ao ouvir de Pandora que o momento seguinte de sua existência seria o nada, se movimenta sobre essa coragem de se auto-afirmar.

Quando esta palavra ecoou - "espera-te a voluptuosidade do nada" -, como um trovão, naquele imenso vale, afigurou-se-me que era o último som que chegava a meus ouvidos; pareceu-me sentir a decomposição súbita de mim mesmo. Então, encarei-a com olhos súplices, e pedi mais alguns anos. (1985, p. 522).

Observamos que não é a eternidade que é posta em questão, mas sim os anos a mais que pede a Pandora. Essa atitude de Brás Cubas revela nitidamente a consciência de que a vacuidade é uma expressão da ameaça do não-ser e que o resultado da equação apresentada não pode ser outro termo senão um prolongamento, mesmo que diminuto, da vida que acontece. ${ }^{186}$ Certamente, nos instantes a mais que pede para viver, Brás Cubas poderia uma vez mais presentificar as experiências de maior expressão vital, como por exemplo, a do amor eros. $\mathrm{O}$ argumento de Pandora tenta convencer Brás Cubas de que a vida sempre resulta num vazio. Sendo assim, o que mais poderia querer o grande lascivo? 186 Tillich denomina de ansiedade o que nomeamos consciência do vazio. A ansiedade seria determinada pela autoconsciência do eu finito como finito. Cf. Paul TILLICH, Teologia sistemática, p. 164. 
Pobre minuto! exclamou. Para que queres tu mais alguns instantes de vida? Para devorar e seres devorado depois? Não estás farto do espetáculo e da luta? Conheces de sobejo tudo o que eu te deparei menos torpe ou menos aflitivo: o alvor do dia. a melancolia da tarde, a quietação da noite, os aspectos da Terra, o sono, enfim, o maior benefício das minhas mãos. Que mais queres tu, sublime idiota? (1985, p. 522)

Se a vitalidade (o amor à vida) é a categoria a partir da qual poderemos interpretar aquilo que toma Brás Cubas incondicionalmente, a resposta do grande lascivo à pergunta derradeira de Pandora (Que mais queres tu, sublime idiota?) não poderia ser outra senão: "Viver somente, não te peço mais nada. Quem me pôs no coração este amor da vida [...] (Op. cit., p. 522).

A experiência radical do ter-que-morrer é o que impulsiona fortemente Brás Cubas para o enfretamento da magnitude da vida ${ }^{187}$. Por mais insensível e despercebido que seja o ser humano dificilmente deixará, de algum modo e ou em algum momento de sua vida, de sentir a indefinível presença ou ausência de algo que o transcende ou que o abarca. ${ }^{188}$ Esta imagem totalizante do ser humano certamente foi contemplada pela estética machadiana. Resta-nos saber de fato se esta força estética presente na literatura de Machado de Assis possui uma singularidade. A exigência que deve ser cumprida diante da literatura machadiana é a de saber se as operações hermenêuticas que empregamos, em alguma medida, confrontam ou mesmo confirmam determinadas interpretações teológicas sobre o ser humano. Temos afirmado que enquanto hermenêutica, a teologia apresentaria, portanto, uma profunda afinidade com o discurso literário, pois tanto a teologia, sob esta nova ótica, quanto a literatura constroem - a partir da capacidade que elas possuem em lidar e de identificar as regiões simbólicas na realidade formas de conhecimento do ser humano e do mundo, que por sua vez fazem apelo às operações de natureza hermenêutica para a revelação do excesso de sentido que caracteriza a maneira pela qual eles são representados por elas.

Temos afirmado e aqui afirmaremos uma vez mais que literatura e teologia são formas autônomas de decodificação dos símbolos universais de onde emergem os aspectos essenciais da vida do ser humano.

187 Cf. Paul TILlICH, Teologia sistemática, p. 296.

188 Cf. Antonio BLANCH, El hombre imaginario, p. 409. 
Quando a literatura é percebida para além da mímesis e da pura representação do real não há, no confronto com a teologia, uma relação de subordinação. Quando se descortinou em Brás Cubas a realização de uma vida intransitiva e impulsionada pelo senso de auto-afirmação emergente no ser humano machadiano, descortinou-se também, segundo nossos pressupostos interpretativos, uma singularidade que acompanha esse ser humano. Estando o ser humano machadiano confrontado com questão da finitude, não há em sua forma de resolver essa questão uma obediência à matriz soteriológica que permeia nossa tradição religiosa e teológica cristãs.

O cristianismo é bom para as mulheres e os mendigos, e as outras religiões não valem mais do que essa: orçam todas pela mesma vulgaridade ou fraqueza [...] Verás - Brás Cubas - o que é a religião humanística [...] é a reconstituição da substância, não o seu aniquilamento ${ }^{189}$

Dissipar a possibilidade da eternidade e o apego radical à vida que acontece transformariam as memórias póstumas, em nossa ótica, numa grande ode à vida sem que ela e a plena superação da finitude dependessem de uma dimensão utópica além da história. O amor incondicional à vida (Viver somente, não te peço mais nada [...] ou Viver não é a mesma coisa de morrer[...]), o amor vivido com Marcela (Gastei trinta dias para ir do Rossio Grande ao coração de Marcela, não já cavalgando o corcel do cego desejo [...]) e depois a descoberta da paixão por Vírgília (Vejam: o meu delírio começou na presença de Virgília; Virgília foi o meu grão pecado da juventude [...] Virgília era o presente; eu queria refugiar-me nele [...] Virgília era o travesseiro do meu espírito $[\ldots]^{190}$ formam o epicentro das memórias. As particularidades da estética machadiana serão mais acentuadamente percebidas quando observarmos que os problemas mais importantes do diálogo da teologia com a vida não estão propriamente na identificação das questões mais radicais como a finitude, por exemplo, mas sim na respostas criativas que somente a literatura e não a teologia tem conseguido apresentar aos dilemas existenciais que já se tornaram consenso para ambas. Não é a exposição da questão radical da finitude a singularidade da estética machadiana, mas sim a possibilidade de o ser humano construído artisticamente vislumbrar que a vida pode se despedir das exigências

189 Esta afirmação é dada por Quincas Borba, amigo de Brás Cubas e criador do humanitismo. Cf. $M p B C$, cap. 157.

190 (Op. cit., p. 522-536-534, 525, 575) 
soteriológicas e mergulhar num processo de auto-afirmação do presente: "Teria de escrever um diário e não umas memórias, nas quais só entra a substância da vida." (Op. cit., p. 544) Por mais que o simbolismo da Vida Eterna encontrado na tradição clássica da teologia aponte, a partir de seu campo de sentido, algo maior do que uma vida perfeita além da história, cremos haver na antropologia machadiana uma dura crítica à eternidade como efetivação objetiva de uma vida sem riscos, pois a eternidade seria uma espécie de consolação suprema ou mesmo de instrumentalização por subordinar a vida de forma repressiva a um processo de salvação.

\section{3. mas que diacho bá absoluto nesse mundo?}

A afirmação da vida (diríamos mais: a afirmação de uma religião da vida) e o senso de vacuidade sempre caminharam juntos diante da existência de Brás Cubas, protagonista do romance que carrega seu nome: "Tantos sonhos, meu caro Borba, tantos sonhos, e não sou nada." (1985, p. 628). A voz que fala em primeira pessoa é a voz de um homem velho, que tem a consciência de que não é mais possível se projetar sobre a vida com mesma intensidade de outrora; portanto 'sabe que morre.' (Op. cit., p. 630). O sentido da vida de Brás Cubas só teve pleno significado quando admitiu que sua vida não deveria se condicionar a nenhuma dimensão teleologicamente construída. Tendo a consciência de que a vida humana será sempre confrontada com seu ocaso, Brás Cubas buscou na invenção de um emplasto uma metáfora para a cura da melancólica existência humana: "divino emplasto, tu me darias o primeiro lugar entre os homens, acima da ciência e da riqueza, porque eras a genuína e direta inspiração dos céus. $\mathrm{O}$ acaso determinou o contrário; e aí vos ficais eternamente hipocondríacos" (Op. cit., p. 639) A pergunta "mas que diacho há absoluto nesse mundo?" pretende-se irônica, porque se tomada no horizonte de sua vida demonstrará que todas as veleidades na verdade deram a ela uma significante concretude: "compreendi que estava velho, e precisava de uma força [...]" "A solidão pesava-me, e a vida era para mim a pior das fadigas [...]"(Op. cit., p. 638). Diante de todas as negativas que recaem sobre uma vida que se pretendeu intensa, porém, finita conscientemente, fica por certo um saldo positivo. Como afirma Brás Cubas, "coube-me a boa fortuna de não comprar o pão com suor do meu rosto" e ainda a derradeira negativa, que é o seu pequeno saldo positivo conquistado na vida: "Não tive filhos, não transmiti a nenhuma criatura o legado da 
nossa miséria." (1985, p. 639).

Cabe-nos ainda uma pergunta: por que não tomamos as intensas experiências de Brás Cubas como espelhos para as nossas próprias vidas? E por que não? 


\section{Referências}

ASSIS, Machado. Obra completa. 5. ed. Rio de Janeiro: Nova Aguilar, 1985. Tomos I e III.

ASSIS, Machado. Obra completa. 2. ed. Rio de Janeiro: Editora José Aguilar, 1962. Tomo II.

BOFF, Leonardo. Tempo de transcendência. Rio de Janeiro: Sextante, 2000.

BLANCH, Antonio. El hombre imaginário. 2. ed. Madrid: Universidad Pontifícia Comillas, 1996.

CONCEIÇÃO, Douglas Rodrigues da. Fuga da promessa e nostalgia do Divino. Rio de Janeiro: Horizonal, 2004.

FAORO, Raimundo. A pirâmide e o trapézio. 3. ed. Rio de Janeiro: Editora Globo, 1988.

GENETTE, Gérard. Palimpsestes. Paris: Éditions du Seiul, 1982 MOLTMANN, Jürgen. O espírito da vida. Petrópolis, RJ: Vozes, 1998. TILLICH, Paul.Teologia sistemática. 2. ed. São Leopoldo, RS: Sinodal, 1987.

TILLICH, Paul. A coragem de ser. 6. ed. São Paulo: Paz e Terra, 2001. 